\title{
Analyzing risks related to the use of pesticides in vegetable gardens in Burkina Faso
}

\author{
Rayim Wendé Alice Narée, *, Paul Windinpsidi Savadogo ${ }^{1}$, Zacharia Gnankambary ${ }^{1}$, \\ Hassan Bismarck Nacro², Michel Papaoba Sedogo ${ }^{1}$ \\ ${ }^{1}$ Laboratoire Sol-Eau-Plante. Institut de l'Environnement et de Recherches Agricoles (INERA), ouagadougou, Burkina Faso \\ ${ }^{2}$ Laboratoire d'Etude et de Recherche sur la Fertilité des Sols (LERF), Université Polytechnique de Bobo Dioulasso (UPB), Bobo Dioulasso, \\ Burkina Faso
}

\section{Email address:}

alice.nare@gmail.com (R-W. A. Naré.), paul.savadogo@gmail.com (P. W. Savadogo), gnank_zach@hotmail.com (Z. Gnankambary), nacrohb@yahoo.fr(H. B. Nacro), michel_sedogo@yahoo.fr(M. P. Sedogo)

\section{To cite this article:}

Rayim Wendé Alice Naré, Paul Windinpsidi Savadogo, Zacharia Gnankambary, Hassan Bismarck Nacro, Michel Papaoba Sedogo. Analyzing Risks Related to the Use of Pesticides in Vegetable Gardens in Burkina Faso. Agriculture, Forestry and Fisheries.

Vol. 4, No. 4, 2014, pp. 165-172. doi: 10.11648/j.aff.20150404.13

\begin{abstract}
In West Africa, the uncontrolled use of pesticides by vegetable farmers leads to contamination of soils as well as surface and ground water. Farmers also use various sources of organic amendments which could impact the fate of the pesticides in soils. This study was conducted to identify the type of pesticides and organic amendments used in the main vegetable gardens in Ouagadougou, Ouahigouya and Bobo-Dioulasso three cities of Burkina Faso. Farmers were interviewed individually on their practices regarding organic amendments and pesticides. Sixty one percent $(61 \%)$ of farmers do not know the instruction regarding the application of pesticides. Fifty three percent (53\%) of farmers did never receive training on pesticide application. We found that pyrethroid-based insecticides like lambda-cyhalothrin and delthametrin were the most used by farmers. About $69 \%, 59 \%$ and $100 \%$ of the farmers apply the pesticides periodically in their fields respectively in Ouagadougou, Ouahigouya and Bobo-Dioulasso. All the farmers interviewed attested that they do not respect the recommended doses of pesticides. Manure was the organic amendment mostly used in the three cities (41-75\%), followed by household garbage (15-41\%). In Ouagadougou most of farmers (69\%) apply organic amendment at the recommended rate or more while in Bobo-Dioulasso (69\%) and in Ouahigouya (57\%), the majority apply low rates. There is a correlation between the social status (sex and the education level) and the pesticide and organic amendment management.
\end{abstract}

Keywords: Soil, Pesticides, Organic Amendment, Environment Pollution, Burkina Faso

\section{Introduction}

In Africa, the use of pesticides accounts for $2-4 \%$ of the world pesticide use [1].Various active ingredients like organophosphates, carbamates, pyrethroids and organochlorins are commonly used in urban vegetable production [2, 3]. In Burkina Faso, approximately one hundred active ingredients are used [4] and around 75\% of these active ingredients are insecticides, acaricides or nematicides [5].

Numerous studies in Africa showed that pesticides are used incorrectly. Those studies revealed that famers use unauthorized or banned products and also have inappropriate practices like the non-use of protection material, [6-9]. Inappropriate use of pesticides negatively impact on farmers and consumers health $[10,11]$, and leads to a contamination of soil [12], water [13-15], air [16-18], and crops [19].

The persistence of endosulfan, profenofos and others organo-chlorin pesticides in the cotton fields in Burkina Faso was reported [20] as well as their effect on microbial activities [21-23].

Soil amendment with animal manure or crop residues is a common practice in in the sub Saharan African agricultural systems. This practice has beneficial effects on soil nutrient status and stimulate soil biology, particularly in degraded and arid environments [24, 25].Organic amendments also play an important role on the fate of pesticides in soil [26]. [27] studied the effects of composts on the adsorption-desorption 
of three carbamate pesticides in different soils. The authors found that the adsorption capacity was positively and significantly correlated with soil organic carbon and the cation exchange capacity and negatively correlated with soil $\mathrm{pH}$. They also found that desorption was more in unamended soil than amended soil.

In Burkina Faso [28] showed that manure applied at the rate of $3.33 \mathrm{mg} / \mathrm{kg}$ of soil increased organo-chlorin pesticide degradation 1.5 time more than unamended soil. .

Whereas numerous studies on pesticides use were conducted in the cotton systems in Burkina Faso, such investigations on vegetable gardens are not well documented. This paper reports on farmers practices regarding the use of pesticides and organic amendments in vegetable gardens in three main cities of Burkina Faso, Ouagadougou, Bobo-Dioulasso and Ouahigouya, and analyses social environment and the risks of environment and human contamination by pesticides. We hypothesized that (i) the types of pesticides used in vegetables farming are not recommended, and they are not managed properly (ii) the organic amendments are not managed properly (iii) farmers social status affects pesticides and organic amendment management.

\section{Materials and Methods}

\subsection{Study Sites}

The survey was conducted in September 2012 in the three cities of Burkina Faso, Ouagadougou in the centre, Ouahigouya in the north and Bobo-Dioulasso in the west. In these cities the biggest vegetable gardens were selected. In those gardens, tomato, onion, cabbage, lettuce and potato are the vegetables mostly grown by farmers [29]. The vegetables are all produced with irrigation with waste water from canals and/or water from well and dams. For soil fertility management farmers apply organic amendments and inorganic fertilizers. They use various types of pesticides for pest and diseases control.

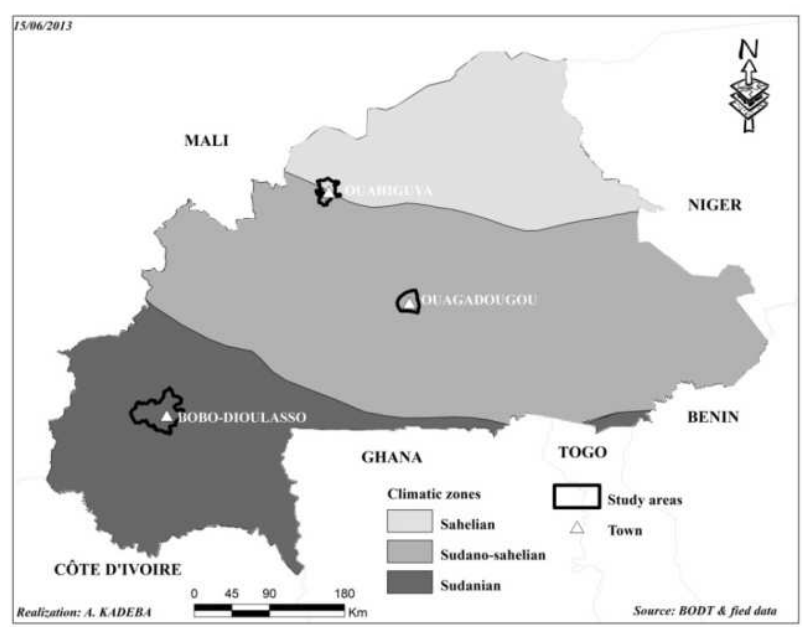

Figure 1. Map of Burkina Faso showing the location of the study areas.
The number of farmers interviewed was 109, 101 and 100 respectively for Ouahigouya, Ouagadougou and Bobo-Dioulasso. The farmers were interviewed on their level of instruction, their knowledge on pesticides and organic amendments. The three studied areas are located in different climate zones of the country (fig1).

\subsection{Survey}

In each zone, a team of surveyors visited farmers. The studied farmers were selected randomly in the three climate zones. The investigations were conducted in four vegetables sites in Ouagadougou (Tanghin, Boulmiougou, Kossodo, and Wayalgin), in BoboDioulasso eight sites (Dogona, Ko-Deni, Sector 25, Sagaby, Kunima, Sabarydougou, Legeuma and Kwa) and in Ouahigouya, 5 sites (Barrage Oumarou Kanazoé, Thiou, Pèla, Gouinré, secteur 05, secteur 14). For the vegetables farms were farmers are organized in associations, we contacted the head of the association to mobilise the others farmers for the interview. The selection of farmers was voluntary basis. A total of 310 farmers were interviewed. We interviewed farmers individually regarding the types and rate of organic amendments and pesticides used. We also collected information on the frequency of application and the equipment used. The information regarding the social status of the farmers was also collected namely sex, age, education level and the affiliation to organizations.

\subsection{Calcul and Statistics}

The percentages and frequencies were calculated using the software Sphinx lexica. The PCA (principal components analysis) was performed using XLSTAT version 6 . The names of the variables were shortened as follow: M: Member of association; M0: not member of association; 0 illeterate; I: primary school; II: secondary school; S0: no sprayer Spest: sprayer; Pa: Periodical pesticides application; A0: application in case of attack; OM1: one time organic amendment; OM2: two time organic amendment; OM3: amendment depending of the availability; OMl: application of organic amendment at less than recommended rate; B: Broadcasting of organic amendment; OMh: application of organic amendment at more than recommended rate; L: localise application of organic amendment; OMu: quantity of organic amendment unknown; LP: localise application of organic amendment followed by ploughing

\section{Results-Discussions}

\subsection{Social Status of Vegetable Farmers}

The majority of farmers were men in Ouahigouya and Bobo Dioulasso while in Ouagadougou, only $46 \%$ of farmers were men (table 1). The average age of farmers was almost the same in the three cities (43 in Ouagadougou ; 37 in Ouahigouya and 39 in Bobo Dioulasso). The highest proportions of illiterate farmers were encountered in Ouagadougou and Bobo-Dioulasso, the two main cities, while in Ouahigouya the highest proportion of farmers having primary and secondary 
education level was recorded. Our results corroborate with those of [30] who reported that in Cameroun, urban agriculture is practiced mostly by youth, illiterate and that urban farmers more often are not organized in association. The high proportion of illiterate farmers in Ouagadougou could be explained by the fact that in big cities educated people are employed in other sectors where a certain level of education is required. Besides, most of the vegetable farmers in big cities are migrants from rural areas who did not have access to education. [31] reported that the majority of vegetable farmers in Burkina Faso are illiterate. The young people involved in vegetable garden secure the labor. The education level (illiterate) could have some consequences on pesticides use. Indeed it might be that illiterate people cannot read the instruction regarding the pesticide use. Besides, they will not be able to write the trainings note for their own use or share with other famers.

Table 1. Social status of vegetable farmers in Burkina Faso (survey conducted in three cities (Ouagadougou, Ouahigouya and Bobo-Dioulasso).

\begin{tabular}{|c|c|c|c|c|}
\hline & Social Status of farmers & Ouagadougou & Ouahigouya & Bobo Dioulasso \\
\hline \multirow{4}{*}{ Age } & Average & 43.03 & 36.69 & 39.37 \\
\hline & Minimum & 18 & 18 & 19 \\
\hline & Maximum & 80 & 55 & 70 \\
\hline & $\mathrm{SD}$ & 12.39 & 9.66 & 12.46 \\
\hline \multirow{3}{*}{ Sex } & Male (\%) & 46 & 96 & 89 \\
\hline & Female (\%) & 54 & 14 & 11 \\
\hline & Illiterate & 87 & 42 & 57 \\
\hline \multirow[t]{2}{*}{ Level of education } & Primary & 6 & 54 & 28 \\
\hline & Secondary & 7 & 13 & 13 \\
\hline \multirow[t]{2}{*}{ Member of farmers associations } & Yes & 56 & 47 & 48 \\
\hline & No & 46 & 53 & 51 \\
\hline
\end{tabular}

\subsection{Pesticides}

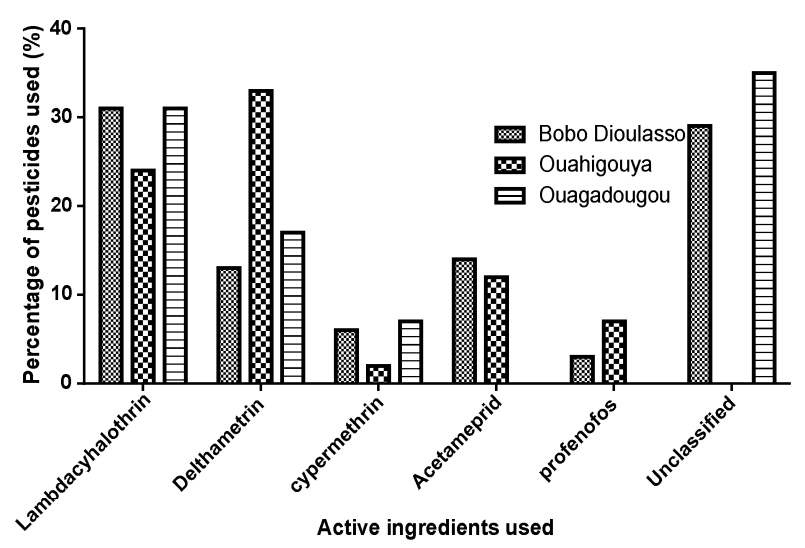

Figure 2. Types of pesticides used by vegetable farmers in three cities of Burkina Faso (Ouagadougou, Ouahigouya and Bobo-Dioulasso)

In the three cities, pyrethroid-based insecticides such as lambda-cyhalothrin and delthametrin were used by a high proportion of the farmers (respectively 24-31\% for lambda-cyhalothrin and $17-33 \%$ for delthametrin) to control insects in vegetable crops (fig 1). Other insecticides like profenofos, cypermethrin, acetamiprid, were used in Ouahigouya and Bobo Dioulasso. Acetamiprid and profenofos were not used in Ouagadougou. The pyrethroids are probably the most available pesticides, explaining the importance of their use as farmers use the products they can easily find. The pyrethroids are highly hydrophobic as shown by their low water solubility and low $\operatorname{KOC}[32,33]$. Some authors [19,
34-38] showed that those type of insecticides are highly toxic to fresh water fish and to bees even at low concentrations $(<0.5 \mathrm{lg} / \mathrm{l})$. The pesticides with low Koc like the pyrethroids are more able to bind to soil particles than pesticides with high Koc value [39, 40]. All the famers interviewed apply pesticides themselves in their farms.

In Ouahigouya and BoboDioulasso almost all the farmers use a spray for pesticides application, whereas in Ouagadougou, only $41 \%$ use this material. The $59 \%$ of farmers in Ouagadougou use other materials like leaves or brooms to apply pesticides. This might be due to the low education level of most of farmers in this city. In the three provinces, farmers spray pesticides periodically (every 3 days or weeks) to prevent insect attack and plants diseases with 59\% in Ouahigouya, 69\% in Ouagadougou, and $100 \%$ in Bobo-Dioulasso. The pesticides quantities used were unknown (table 2). The fact that most of farmers did not get training on pesticide use could explain that situation. In this line $[41,42]$ reported that vegetable farmers have the highest pesticides application frequencies in many African countries. According to [11, 43, 44], inappropriate use of pesticides leads to negative impact on users and consumers health, and vegetation, soil, water and air. Indeed, [20] showed that in Burkina Faso, the soils in the cotton fields were contaminated by endosulfan in the level of 1 to $22 \mu \mathrm{g} / \mathrm{kg}$ in farmer fields. [12] reported that three months after application, endosulfan and profenofos concentration varied in the range of $10-30 \mu \mathrm{g} / \mathrm{kg}$ in cotton field in Burkina Faso. The impact of pesticides on human health was also reported. Approximately three million people are poisoned and 200,000 die each year around the world from pesticide 
poisoning and a majority of them belongs to the developing countries $[45,46]$.

Table 2. Practices of pesticides application by vegetable farmers in three cities of Burkina Faso (Ouagadougou, Ouahigouya and Bobo-Dioulasso).

\begin{tabular}{lllll}
\hline & \multicolumn{3}{l}{ Percentage of responses (\%) } \\
\hline Pesticides management & & Ouagadougou & Ouahigouya & Bobo-Dioulasso \\
\hline Mode of pesticides application & Spraying & 41 & 99 & 100 \\
& Other & 59 & 0 & 0 \\
Frequency of application & Periodically & 69 & 59 & 100 \\
& In case of attack & 27 & 24 & 0 \\
Pesticides dosage & Precise & 0 & 0 & 0 \\
& Not Precise & 100 & 100 & 54 \\
Training on the use of pesticides & Yes & 36 & 34 & 46 \\
& No & 64 & 66 & \\
\hline
\end{tabular}

\subsection{Organic Amendments}

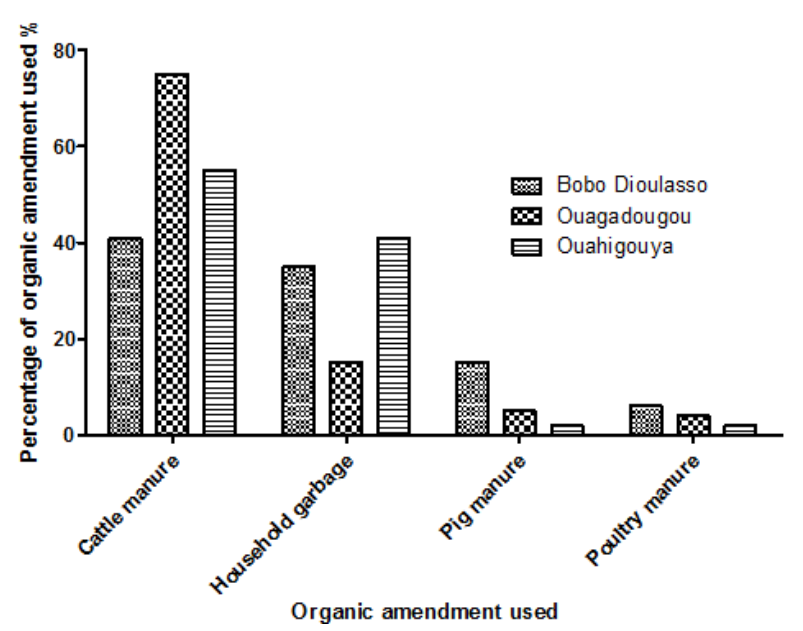

Figure 3. Types of organic amendment applied in vegetable gardens in three cities of Burkina Faso (Ouagadougou, Ouahigouya and Bobo-Dioulasso)

Manure was the most used organic amendment in all the three cities (41-75\%), followed by the household garbage (15-41\%) (fig 3). In Ouagadougou, the cattle manure was used by $75 \%$ of famers, while in Ouahigouya and Bobo Dioulasso it was $55 \%$ and $41 \%$ respectively. Household garbage was used by $41 \%$ of farmers in Ouahigouya, followed by Bobo-Dioulasso (35\%) and Ouagadougou (15\%). The other organic amendments (pig manure, poultry manure and urban compost) were used but not significantly (less than $20 \%$ of farmers). In many West Africa countries, organic amendments are used in vegetable gardens. In Lomé (Togo), organic amendments are used in all the city gardens [2]. In Dakar (Senegal), it has been estimated that $25 \%$ of the nutrients for horticultural crops come from compost, $25 \%$ from animal manure [47].

Table 3. Quantities of organic amendment applied by vegetable farmers in three cities of Burkina Faso (Ouagadougou, Ouahigouya and Bobo-Dioulasso)

\begin{tabular}{llll}
\hline \multicolumn{4}{l}{ Percentage of responses (\%) } \\
\hline Quantities (T/ha) & Ouagadougou & Ouahigouya & Bobo Dioulasso \\
\hline$<10$ & 8 & 47 & 20 \\
$10-19$ & 25 & 10 & 49 \\
$20-40$ & 55 & 39 & 7 \\
$>40$ & 4 & 1 & 6 \\
Unknown & 8 & 3 & 18 \\
\hline
\end{tabular}

The quantities of organic amendments applied by farmers varied between the three cities (table 3). In Ouagadougou most of the farmers $(69 \%)$ used organic amendments at $20 \mathrm{t} / \mathrm{ha}$ which is the recommended rate or even more. However in Ouahigouya and Bobo-Dioulasso, the majority (respectively $57 \%$ and $69 \%$ ) use less than the recommended rate. In Ouagadougou and Bobo-Dioulasso, most of farmers apply organic amendment one time during the plant cycle (respectively $76 \%$ and 56\%). In Ouahigouya and Ouagadougou the organic amendments are spread on the fields (77\% and 98\% respectively) while in Bobo-Dioulasso $58 \%$ of farmers practice localise application and $14 \%$ of those farmers plough in the amendments after application.

Table 4. Methods of application of organic amendments by vegetable farmers in three cities of Burkina Faso (Ouagadougou, Ouahigouya and Bobo-Dioulasso).

\begin{tabular}{lccc}
\hline & Ouagadougou & Ouahigouya & Bobo-Dioulasso \\
\hline Frequency of application & 76 & 13 & \\
\hline One-time & 10 & 5 & 20 \\
Two-times & 14 & 80 & 21 \\
$\begin{array}{l}\text { Depending of } \\
\text { avaibility }\end{array}$ & & & \\
Application methods & 98 & 77 & 15 \\
$\begin{array}{l}\text { Broadcast } \\
\text { Localise }\end{array}$ & 0 & 10 & 58 \\
Localise- & 0 & 0 & 14 \\
ploughing in & & & \\
\hline
\end{tabular}

The use of organic amendments can lead to pesticide adsorption or to their degradation. The sorption of uncharged organic compounds like pyrethroids in soils has been shown to be highly correlated with soil organic matter content [48, 49]. In the three cities, the use of organic amendments could be an opportunity to reduce surface and groundwater pollution as soil sorption is one of the most important processes affecting the fate of pesticides in the environment [50]. Many studies highlighted the effects of soil organic amendments on pesticides retention and degradation. They showed that pesticides are adsorbed on both organic and inorganic soil constituents [51, 52]. In general, addition of organic matter, including soluble and insoluble fractions, increases the pesticides adsorption and decreases their subsequent mobility in the soil profile $[53,54]$. According to [50] for all those pesticides which have low polarity and water solubility like the pyrethroids soil organic matter will be the important 
sorbent, simply because the solvent is water and hydrophobic interactions are the driving force. Lambda-cyhalothrin because of its high hydrophobicity is sorbed more strongly by soil particles than deltamethrin and cypermethrin [55]. Regarding the sorption affinity the three pyrethroids are ranged as follow

lambda-cyhalothrin $>$ deltamethrin $>$ cypermethrin.

In Bobo Dioulasso and Ouagadougou where lambda-cyhalothrin is the most used active ingredient, and cattle manure is used by most of farmers, water pollution probably will be reduced. In Ouahigouya where deltamehrin is the most used pesticide, water is likely to be polluted by pesticide compared to the other cities. Hydrophobic sorption to mineral surfaces may decrease the rate of chemical and biological degradation [55]. However, pyrethroids when used as soil insecticides are not selective and may also kill beneficial soil microorganisms [56].

\subsection{Impact of the Social Status of Famers on Pesticides and Organic Amendment Management}

The principal component analysis (PCA) show that the first axis F1(65\% of the variability) was positively correlated with female farmers, age, illiteracy, affiliation to farmers' association, pesticides application in case of pest attack, the broadcast of organic amendment, the application of high rate of organic amendment (fig 4).

This axis was negatively correlated with the male farmers, primary and secondary education level, not member of farmers' cooperative, use of organic amendments according to the availability, and application of organic amendments at less than recommended rate, localise application of organic amendments.

The second axis F2 was positively correlated with age, illiteracy and secondary education level, periodically application of pesticides, one and two time of organic amendment application, application of organic amendment at low rate, localise application of organic amendment. This axis was negatively correlated with farmers sex (male and female), other methods for pesticides application, application in case of pest attack, application of organic amendment at high rate.

The individual PCA showed positive correlation with two provinces (Ouahigouya and Bobo Dioulasso) and negative correlation with Ouagadougou. The PCA revealed a strong correlation between the sex, the affiliation of farmers to association, the education level and the management of pesticides and organic amendments. In fact women are illiterate, member of farmers' association, and they use pesticide in case of attack and use material other than sprays for pesticides application. They broadcast organic amendment at a rate higher than recommended. Men have primary education level, not member of farmers association, and they use organic amendments according to the availability. In most of the sub Saharan countries including Burkina Faso the education rate is low [57] mostly for women. It was reported that women education level in Burkina Faso was 37.2\% for primary school in 2002 and
$8.51 \%$ for secondary school in 1999 [58]. This low rate corroborate with our results. Although women are member of association meaning that they could benefit of trainings on pesticides use, they do not adopt a good practice regarding the application of pesticides. This could be explained by the fact that the materials are inaccessible for women because men are the manager most of the time. This confirms a social influence on women activities. [59] showed the relation between technology adoption and farmers' socio-economic status in Burkina Faso. They reported that the gender and the age are the factors influencing the technologies adoption by farmers. The same finding was reported by [60] for compost adoption by farmers in Cameroon.
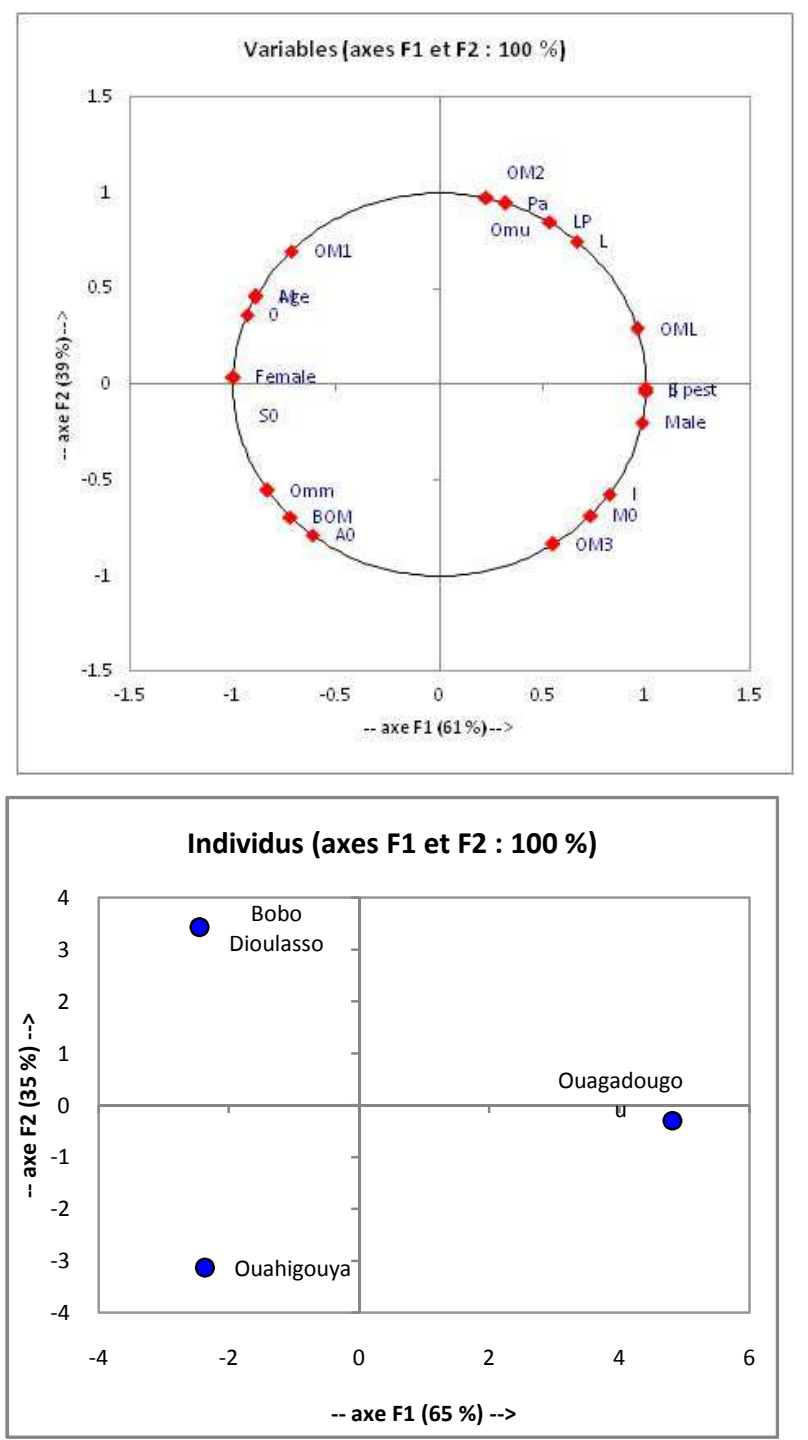

Figure 4. Principal Component Analysis showing the impact of the social status of farmers on the use of pesticides and vegetables in three cities (Ouagadougou, Ouahigouya and Bobo Dioulasso) in Burkina Faso.

\section{Conclusion}

The survey showed that nearly all farmers in the three cities use pyrethroids based insecticides. Most of the farmers in 
these cities are not instructed and did not receive training on pesticide use. The majority use leaves or broom (brushes or twigs) for pesticides application in Ouagadougou. All farmers use organic amendments, but it is only in Ouagadougou where organic amendments were used at the recommended rate or more. The use of organic amendment use could contribute to pesticides retention. There is urgent need for more training on pesticides and organic amendment use so that farmers will be able to use pesticide correctly and improve their efficiency. This will contribute to environment, users and consumers health protection and to a sustainable agriculture. From our results we conclude that for a safe use of pesticides in vegetable gardens, women education level need to be increased and more training on pesticides and organic amendment use need to be provided. The researches on the use of bio-pesticides are also needed.

\section{Acknowledgements}

This work was financed by International Foundation for Science (IFS) through grant number C/5002-1 awarded to the first author. We are grateful to IPICS and RAPFE for the publication fee, and Dr Kiba Delwendé Innocent Agronomist at INERA (Burkina Faso) for comments on the draft of the manuscript.

\section{References}

[1] Agrow. World agchem market steady. AGROW 4979 June 2006,. 2006:17.

[2] Tallaki K. The pest-control system in the market gardens of Lomé, Togo. in: Mougeot LJA (Ed), Agropolis: the social, political and environment dimensions of urban agriculture, IRDC, Ottawa, Canada, . 2005:pp. 51-88.

[3] Cissé I, Fall ST, Akinbamijo OO, Diop YM. L'utilisation des pesticides et leurs incidences sur la contamination des nappes phréatiques dans la zone des Niayes au Sénégal. in: Akinbamijo OO, Fall ST, Smith OB (Eds), Advances in crop-livetsock integration inWest African cities, ITC, ISRA, CRDI, Ottawa, Canada, . 2002: pp. 85-99.

[4] Toé MA. Limites maximales de résidus de pesticides dans les produits agricoles d'exportation dans trois pays du CILSS. Etude du Burkina Faso. . Projet Gestion des pesticides au Sahel http://wwwinsahorg/pdf/cataloguePublicationpdf. 2003:pp. $1-3$.

[5] Orou Guidou G. La campagne cotonnière 97/98 au Bénin. In: Symposium sur l'utilisation des intrants en culture cotonnière et maraîchère. Dakar, 25-28 janvier. 1998:pp. 49-52.

[6] Gomgnimbou APK, Savadogo PW, Nianogo AJ, Millogo-Rasolodimby J. Usage des intrants chimiques dans un agrosystème tropical : diagnostic du risque de pollution environnementale dans la région cotonnière de l'est du Burkina Faso. Biotechnol Agron Soc Environ. 2009;13(4):499-507.

[7] Addo S, Birkinshaw LA, Hodges RJ. Ten years after the arrival of Larger Grain Borer: farmers' responses and adoption of IPM strategies. Int J Pest Manage. 2002;48(4): 315-25.
[8] Dinham B. Growing vegetables in developing countries for local urban populations and export markets: problems confronting small-scale producers. Pest Manage Sci. 2003;59:575-82.

[9] Matthews G, Wiles T, Baleguel P. A survey of pesticide application in Cameroon. Crop Prot 2003;22:707-14.

[10] Kishi M. The health impacts of pesticides: what do we now know? In:Pretty, J (Ed), The Pesticide Detox Towards a More Sustainable Agriculture Earthscan, London. 2005:pp. 23-38.

[11] Ahouangninou C, Fayomi BE, Martin T. "Evaluation des Risques Sanitaires et Environnementaux des Pratiques Phytosanitaires des Producteurs Maraîchers dans la Commune Rurale de Tori-Bossito (Sud-Bénin)" Cahiers Agricultures. 2011; Vol. 20(No. 3): pp. 216-22.

[12] Ondo Zue Abaga N, Alibert P, Dousset S, Savadogo PW, M. S, M. S. Insecticide residues in cotton soils of Burkina Faso and effects of insecticides on fluctuating asymmetry in honey bees (Apis mellifera Linnaeus). Chemosphere 2011;83:585-92.

[13] Leu C, Singer H, Stamm C, Muller S, Schwarzenbach R. Variability of herbicide losses from 13 fields to surface water within a small catchment after a controlled herbicide application. . Environ Sci Technol. 2004;38(14):3835-41.

[14] Panuwet P, Siriwong W, Prapamontol T, Barry Ryan P, Fiedler $\mathrm{N}$, Robson MG, Boyd Barr D. Agricultural pesticide management in Thailand: status and population health risk. environmental science $\&$ policy $2012 ; 17 \quad 72-81$.

[15] Tapsoba HK, Bonzi-Coulibaly YL. Production cotonnière et pollution des eaux par les pesticides au Burkina Faso. J Soc Ouest-Afr Chim. 2006;21:87-93.

[16] Aulagnier F, Poissant L. Some pesticides occurrence in air and precipitation in Québec, Canada. . Environ Sci Technol. 2005;39:2960-7.

[17] Manirakiza P, Akinbamijo O, Covaci A, Pitonzo R, Schepens P. Assessment of Organochlorine Pesticide Residues in West African City Farms: Banjul and Dakar Case Study. Arch Environ Contam Toxicol 2003;44:171-9.

[18] Adu-Kumi S, Kareš R, Literák J, Boru vková J, Yeboah PO, Carboo D, Akoto O, Darko G, Osae S, Klánová J. Levels and seasonal variations of organochlorine pesticides in urban and rural background air of southern Ghana. Environmental Science and Pollution Research 2012;19 (6):1963-70.

[19] Ahouangninou C, Martin T, Edorh P, Bio-Bangana S, Samuel O, St-Laurent L, Dion S, Fayomi B. Journal of Environmental Protection. 2012;3:241-8.

[20] Savadogo WP, Traoré O, Topan M, Tapsoba KH, Sédogo PM, Bonzi-Coulibaly LY. Variation de la teneur en résidus de pesticides dans les sols de la zone cotonnière du Burkina Faso. Journal Africain des Sciences de l'Environnement. 2006;1:29-39.

[21] Naré R-WA, Savadogo WP, Gnankambary Z, Sedogo PM. Effect of Endosulfan, Deltamethrin and Profenophos on Soil Microbial Respiration Characteristics in Two Lands Uses Systems in Burkina Faso. Research Journal of Environmental Sciences. 2010;4(3):261-70.

[22] Ouattara B, Savadogo PW, Traoré O, Coulibaly B, Sedogo PM. Effet des pesticides sur l'activité microbienne d'un sol ferrugineux tropical au Burkina Faso. Cameroun Journal of Experimental Biology. 2010; Vol $06 \mathrm{~N}^{\circ}$ 01:11-20. 
[23] Naré R-WA, Savadogo WP, Gnankambary Z, Nacro HB, Sedogo PM. Effect of Three Pesticides on Soil Dehydrogenase and Fluorescein Diacetate Activities in Vegetable Garden in Burkina Faso. Curr Res J Biol Sci. 2014;6(2):102-6.

[24] Ouédraogo E, Mando A, Zombré NP. Use of compost to improve soil properties and crop productivity under low input agricultural system in West Africa. . Agr Ecosyst Environ. 2001 $84: 259-66$.

[25] Ros M, Hernandez MT, Garcia C. Soil microbial activity after restoration of a semiarid soil by organic amendments. Soil Biol Biochem. 2003;35:463-9.

[26] Kumar A, Singh S. Adsorption and Desorption Behavior of Chlorotriazine Herbicides in the Agricultural Soils. J Pet Environ Biotechnol. 2013;4(5):154.

[27] Bansal OP. The Effects of composts on adsorption-desorption of three carbamate pesticides in different soils of Aligarh district. J Appl Sci Environ Manage. 2010;14 (4):155 - 8.

[28] Savadogo PW, Lompo F, Bonzi-Coulibaly YL, Traoré AS, Sedogo PM. Influence de la Température et des Apports de Matière Organique sur la Dégradation de l'Endosulfan dans trois types de Sols de la Zone Cotonnière du Burkina Faso. J Soc Ouest-Afr Chim 2008;026:79 - 87.

[29] Bassolé D, Ouédraogo L. Problématique de l'utilisation des produits phytosanitaires en conservation des denrées alimentaires et en maraîchage urbain et péri urbain au Burkina Faso : cas de Bobo Dioulasso, Ouahigouya et Ouagadougou. IFDC 2007.

[30] Sotamenou J, Parrot L. Sustainable urban agriculture and the adoption of composts in Cameroon. International Journal of Agricultural Sustainability. 2013;11(3):282-95.

[31] Smith OB. Overview of urban agriculture and food security in West Africa. International Development Research Centre, Ottawa, Canada. 2001.

[32] Wauchope RD, Buttler TM, Hornsby AG, Augustun Beckers PWM, Burt JP. The SCS/ARS/CES pesticides properties for environmental decision-making. . Rev Environ Contam Toxicol. 1992;123:1-155.

[33] Tomlin CDS. The Pesticide Manual 11th ed. British Crop Protection Council, UK. 1997.

[34] Edwards R, Millburn P. The metabolism and toxicity of insecticides in fish. . In: Hutson, DH, Roberts, TR (Eds), Insecticides, vol 5 John Wiley and Sons, New York. 1985:pp. 249-69.

[35] Murty AS. In: Toxicity of Pesticides to Fish. CRC Press, Inc, Florida. 1986a; vol. 1.

[36] Murty AS. In: Toxicity of Pesticides to Fish. CRC Press, Inc, Florida. 1986b; vol. 2.

[37] Wise, Ltd. LIS. The e-Pesti-cide Manual 2000-2001 (Twelve Edition). Version 20 Editor: CDS Tomlin; British Crop Protection Council.

[38] Hertfordshire Uo. Base de Données FOOTPRINT PPDB sur les Propriétés des Pesticides. FOOTPRINT: Des Outils Innovant Pour l'Evaluation et la Réduction du Risque Pesticides. 2008:http://www.eu-footprint.org/fr/ppdb.html.

[39] Elliott JA, Cessna AJ, Nicholaichuk W, Tollefson LC. Leaching rates and preferential flow of selected herbicides through tilled and untilled soil. Journal of Environmental Quality 2000;29:1650-6.

[40] Vereecken H. Mobility and leaching of glyphosate: a review. Pest Management Science 2005;61:1139-51.

[41] Williamson S, Ball A, Pretty J. Trends in pesticide use and drivers for safer pest management in four African countries. Crop Protection 2008;27:1327- 34.

[42] Ouédraogo M, Tankoano A, Ouédraogo T, Guissou I. Environ Risque Sante. Risk factors for pesticide poisoning among users in the cotton-production region of Fada N'Gourma in Burkina Faso / Etude des facteurs de risques d'intoxications chez les utilisateurs de pesticides dans la région cotonnière de Fada N'Gourma au Burkina Faso. 2009;8:343-7.

[43] Pretty J, Hine R. Pesticide use and the environment. In: Pretty, J (Ed), The Pesticide Detox Towards a More Sustainable Agriculture Earthscan, London,. 2005:pp. 1-22.

[44] Tariq M, Hussain. I, S. A. Policy measures for the management of water pollution in Pakistan. Pak J Environ Sci 2003;3:11-5.

[45] WHO. Public health impact of pesticides used in agriculture. World Health Organization, Geneva. 1990.

[46] FAO. Project concept paper. HEAL:health in ecological agricultural learning. Prepared by the FAO programme for community IPM in Asia. [http://wwwfaoorg/nars/partners/2nrm/proposal/ 9-2-6doc]. 2000 .

[47] Fall ST, Cissé I, Akinbamijo OO, Adediran SA. Impact de l'intégration entre l'horticulture et l'élevage sur la productivité des systèmes périurbains dans l'espace sénégambien in: Akinbamijo OO, Fall ST, Smith OB (Eds),Advances in crop-livetsock integration inWest African cities, ITC, ISRA, CRDI, Ottawa, Canada,. 2002:pp.69-84.

[48] Clausen L, Fabricius I, Madsen L. Adsorption of pesticides onto quartz, calcite, kaolinite, and $\alpha$-alumina. J Environ Qual. 2001;30:846-57.

[49] Wauchope RD, Yeh S, Linders JB, Kloskowski R, Tanaka K, Rubin B. Pesticide soil sorption parameters: theory, measurement, uses, limitations and reliability. . Pest Manage Sci. 2002;58(5):419-45.

[50] Tang X, Zhu B, Katou H. A review of rapid transport of pesticides from sloping farmland to surface waters: Processes and mitigation strategies.Journal of Environmental Sciences. 2012;24(3):351-61.

[51] Wang H, Huang B, Shi X, Darilek JL, Yu D, Sun W, Zhao Y, Chang Q, Öborn I. Major nutrient balances in small-scale vegetable farming systems in peri-urban areas in China. Nutr Cycl Agroecosyst 2008;81:203-18.

[52] Li L-L, Huang L-D, Chung R-S, K-H. F, Zhang.Y-S. Sorption and Dissipation of Tetracyclines in Soils and Compost. . Pedosphere. 2010;20(6):807-16.

[53] Briceño G, Palma G, Durán N. Influence of organic amendment on the biodegradation and movement of pesticides. Critical Reviews in Environmental Science and Technology. 2007;37: 233-71.

[54] Si YB, Zhang J, Wang SQ, Zhang LG, Zhou DM. Influence of organic amendment on the adsorption and leaching of ethametsulfuron-methyl in acidic soils in China. Geoderma. 2006;130:66-76. 
[55] Oudou HC, Hansen HCB. Sorption of lambda-cyhalothrin, cypermethrin, deltamethrin and fenvalerate to quartz, corundum, kaolinite and montmorillonite. Chemosphere. 2002;49:1285-94.

[56] Matsumura F. In: Toxicology of Insecticides. Plenum Press, New York. 1985; vol. 2.

[57] INSD. (RGPH, Enquête prioritaire, Enquête burkinabé sur les conditions de vie des ménages 2003 et Enquête QUIBB), Direction des Etudes et de la Planification du Ministère de l'Enseignement de Base et de l'Alphabétisation -DEP/MEBA. Direction des Etudes et de la Planification du Ministère des Enseignements Secondaire, Supérieur et de la Recherche
Scientifique -DEP/MESSRS 2003; annuaires.

[58] Paré-Kaboré A. La problématique de l'éducation des filles au Burkina Faso GUFNU-Dijon 1/10. 2003.

[59] Somda J, Nianogob J, Nassa S, Sanou S. Soil fertility management and socio-economic factors in crop-livestock systems in Burkina Faso: a case study of composting technology. . Ecological economics. 2002;43:175-83.

[60] Sonnemann I, Baumhaker H, Wurst S. Species specific responses of common grassland plants to a generalist root herbivore (Agriotes spp. larvae). Basic and Applied Ecology. 2013;13(7):579-86. 